\title{
PEER-NGL Project: Open Source Global Database and Model Development for the Next-Generation of Liquefaction Assessment Procedures
}

\author{
J. P. Stewart ${ }^{1 *}$, S. L. Kramer ${ }^{2}$, D. Y. Kwak ${ }^{1}$, M. W. Greenfield ${ }^{2}$, R. E. Kayen ${ }^{3}$, K. Tokimatsu ${ }^{4}$, J. \\ D. Bray ${ }^{5}$, C. Z. Beyzaei ${ }^{5}$, M. Cubrinovski ${ }^{6}$, T. Sekiguchi ${ }^{7}$, S. Nakai ${ }^{7}$, and Y. Bozorgnia ${ }^{8}$ \\ ${ }^{1}$ Civil \& Env. Eng., 5731 Boelter Hall, University of California, Los Angeles, USA \\ ${ }^{2}$ Civil \& Env. Eng., University of Washington, Seattle, USA \\ ${ }^{3}$ Senior Scientist, US Geological Survey, Menlo Park, USA \\ ${ }^{4}$ Arch. \& Bldg Eng., Tokyo Institute of Technology, Tokyo, Japan \\ ${ }^{5}$ Civil \& Env. Eng., University of California, Berkeley, USA \\ ${ }^{6}$ Civil \& Natural Resources Eng., University of Canterbury, Christchurch, New Zealand \\ ${ }^{7}$ Urban Env. Syst., Chiba University, Chiba, Japan \\ ${ }^{8}$ PEER, University of California, USA
}

\begin{abstract}
The Next-Generation Liquefaction (NGL) project was launched to (1) substantially improve the quality, transparency, and accessibility of case history data related to ground failure; (2) provide a coordinated framework for supporting studies to augment case history data for conditions important for applications but poorly represented in empirical databases; and (3) provide an open, collaborative process for model development in which developer teams have access to common resources and share ideas and results during model development. Work to date has focused on compiling high-value case histories, developing a database template, and planning for needed supporting studies. We describe the project motivation, explain and illustrate how data resources will be compiled and organized, summarize preliminary results from ongoing data collection, describe needed supporting studies, and review project status and next steps.
\end{abstract}

Keywords: NGL, liquefaction database; case history; liquefaction model

*Corresponding author. E-mail: jstewart@ seas.ucla.edu; Tel.: +1 (310) 206-2990 


\section{Introduction}

Early efforts toward the development of procedures for evaluation of liquefaction potential were based on laboratory testing. Since undisturbed sampling of the types of loose, clean, saturated sands known to have been involved in early documented cases of liquefaction is extremely difficult, tests were performed on reconstituted soil specimens. These tests provided valuable insights into the effects of factors such as soil density, effective confining pressure, and cyclic shear stress amplitude on liquefaction resistance, but it was eventually discovered that test specimens prepared to the same densities but by different procedures exhibited very different liquefaction resistances when tested under identical stress and loading conditions. The differences were attributed to differences in soil fabric produced by the different specimen preparation procedures. Combined with potential age effects, the direct applicability of laboratory test results to field conditions was recognized as tenuous.

At that time, the standard of practice for evaluation of liquefaction potential shifted to a basis rooted in in situ behavior as interpreted from field case histories. Case histories of sites where potentially liquefiable soils were shaken during earthquakes were investigated with both site conditions and ground motions characterized. Sites where liquefaction occurred, as indicated by surficial evidence such as sand boils and ground cracking, were noted as were sites with no observed ground failure. The characteristics of the case histories were condensed into measures of loading, most commonly a magnitude-corrected cyclic shear stress ratio, and resistance, typically expressed in terms of penetration resistance. By plotting the case histories on axes of loading and resistance, combinations corresponding to liquefaction and non-ground failure could be identified. In the early stages of case history-based evaluation of liquefaction potential, the boundary between liquefaction cases and non-ground failure cases was drawn by hand in a 
generally conservative manner. More recently, Bayesian analysis procedures have been used to evaluate probabilities of liquefaction, taking into consideration uncertainties associated with individual data points and variabilities among the central values of distinct data points.

To date, research on liquefaction triggering and effects has occurred within the traditional framework of individual or small groups of researchers assembling and interpreting case history data to support the development of predictive models. Liquefaction case history databases have been developed based upon the initiative, effort, and personal connections and data inventories that individual researchers or research teams have been able to assemble over time. Typically only the team of researchers that assembled a particular database has had access to its source data. As a result, the databases have been of different size, breadth, and quality, and their vetting by only small groups of researchers has complicated the identification of potentially problematic data.

Under the traditional framework, the groups that assemble case history databases also develop empirical predictive models. Research groups work independently to interpret individual case histories, a process that often requires judgment and subjective decisions. In this framework, the models developed by individual groups have often indicated different behavior due to differences in their databases, different interpretations of the data in their databases, potential errors in data interpretation, different approaches to constraining model behavior under data-poor conditions, and different philosophies of model development. Detailed discussions of subjective and philosophical decisions related to the interpretation of case history data, which can strongly affect model behavior, have rarely been published. In the end, the general opacity of the model development process leads to differences that cannot be clearly understood and judged by 
practitioners. This is clearly inefficient and undesirable. Unfortunately this is also the present state of liquefaction models in the US and elsewhere.

The Next Generation Liquefaction (NGL) project has been conceived by researchers at the Pacific Earthquake Engineering Research (PEER) center in California and partnering organizations globally as a new paradigm for ground failure research and engineering model development. As will be described in this paper, NGL activities thus far have targeted documentation of high-value case histories from recent earthquakes in Japan and New Zealand and supported many workshops that have contributed to the conceptual development of NGL. Over the long-term, the goals of NGL are to coordinate activities of international partners in support of a community database for liquefaction and related ground failure case histories. Moreover, we envision that distinct model teams will utilize this common database, in combination with results from supporting studies of key effects poorly constrained by available data, to develop next-generation models for liquefaction susceptibility, triggering, and effects in a much more transparent and collaborative manner than has been possible previously.

Subsequent sections of this manuscript explain the NGL project vision, scope, organization, and status; describe data products, including illustration of what constitutes a case history; summarize data collection efforts that have been completed thus far; describe the role of supporting studies; and present anticipated products and next steps.

\section{NGL Project Vision and Objectives}

Procedures for engineering assessment of liquefaction hazards are based to a large extent on the interpretation of field performance data from sites that have or have not experienced ground failure attributable to liquefaction. In this context, ground failure refers to permanent 
displacements of the ground surface, which can be caused by liquefaction or other phenomena such as cyclic softening of clays or seismic compression of unsaturated soils. The number of case histories supporting liquefaction procedures is remarkably small. For example, while nearly 200400 case histories support most modern liquefaction triggering procedures, typically only a few dozen of these most tangibly affect the position of the threshold curve. Empirical procedures for analysis of undrained residual strength of liquefied soils are also controlled by only a few dozen case histories. Given the small number of most relevant case histories, it is no surprise that existing databases are incomplete, meaning they cannot constrain important components of engineering predictive models.

This situation can now be improved by substantial increases in the size and quality of field performance data sets. The database expansion is to a large extent associated with the 2011 earthquakes in Japan and New Zealand, which caused a great deal of damage attributable to liquefaction and its effects. However, numerous other earthquakes have produced data that has not yet been considered in most of the current liquefaction triggering and effects models, including the 1999 events in Turkey and Taiwan, 2004 and 2007 events in western Japan, the 2008 event in Greece, 2010 events in Chile and Mexico, and the 2012 event in Italy. We describe some of the unique opportunities afforded by recent case histories subsequently in this paper.

To fully realize the benefits of new and existing data resources, fundamental changes are needed in the manner by which data are collected and analyzed. As described in the Section 1, the traditional research approach is somewhat opaque regarding database development and case history interpretation. This complicates the task of practitioners to select the best of the available models for a particular application. Difficulties occur when the research community is unable to put forth clear standards on best practices, which is the current state of affairs for most important 
problems in liquefaction hazard assessment, including susceptibility, triggering, residual strength, and the analysis of displacements. The ongoing National Research Council (NRC) study [1] was undertaken to respond to this lack of clarity, although the recommendation of specific models was not part of the committee's scope.

NGL was established to support the development of a community database for liquefaction case histories, to facilitate studies on key effects poorly constrained by the database, and to establish a collaborative framework for model development by distinct teams drawing upon common resources. Our vision is that the process of database development, supporting studies, and model development would be undertaken with regular communication among investigators via project coordination meetings and with public workshops to enable community engagement and input. A major benefit of this approach is that the resulting model predictions would reflect genuine, 'apples-to-apples', epistemic variability associated with alternate methods of interpreting a common data set, which is not the case today.

This approach is motivated in part by the success of the Next-Generation of Attenuation (NGA) projects for ground motion prediction [2,3], which developed this research approach and enjoyed substantial global buy-in and broad application.

\section{NGL Data Products}

The NGL database will consist, at its core, of a GIS platform documenting as completely as practical individual case histories of liquefaction, ground failure or non-ground failure (where 'ground failure' indicates permanent ground displacement). Attribution of data sources will be

provided, but data will be presented in a common format. A usable case history of field performance generally requires the following attributes: 
- Observations of field performance from post-event reconnaissance. This can vary from notes and photographs to relatively detailed mapping efforts producing ground failure displacement measurements.

- Depositional history. This includes geology, age, depositional environment, occurrence of liquefaction from previous earthquakes, previous ground mitigation, and constriction records for man-made fill.

- Geotechnical data. Required information on geotechnical conditions at a site of interest includes the soil stratigraphy, ground water depth, details pertaining to soil type (typically from gradation and index tests), and penetration resistance. Information on shear wave velocity is also desirable.

- Ground motions. The characterization of ground motion most often involves intensity measures such as peak acceleration, pseudo-spectral acceleration, or cumulative absolute velocity, but increasingly also may include full waveforms that are used to judge the presence and timing of liquefaction triggering.

The present availability of this information has been assessed through literature review [4-6] and seven workshops held to date in California and Japan. The number of currently available case histories in recent liquefaction triggering models are 230 for borehole/standard penetration test-based site characterization [5], 268 for cone penetration test-based site characterization [7], and 422 for shear-wave velocity-based site characterization [8]. As part of the NGL project, we seek to significantly expand the size and breadth of the data set using observations from relevant events that are either missing from or not adequately represented in the existing inventories. Those events include the 1999 Kocaeli Turkey, 1999 Chi Chi Taiwan, 2004 and 2007 events near Niigata Japan, 2008 Patras Greece, 2010 Maule Chile, 2010 El 
Mayor-Cucapah Mexico, 2010-2011 Canterbury New Zealand, 2011 Tohoku Japan, and 2012 Emilia Italy earthquakes.

We argue that the NGL database as archived in a GIS platform is for practical purposes objective, in that it reports factual information on field performance, geotechnical conditions, and seismic demands. NGL will also populate a Flatfile, which will contain a synthesis of parameters used for model development. The process of distilling the information from the database to the format required for a flatfile is subjective. We illustrate through example the contents of the database and flatfile in the subsections below, including discussion of the subjective decisions required to produce a flatfile data point.

\subsection{NGL GIS Database}

The GIS database is intended to document as completely as practical (and in a common format), case histories of liquefaction, related ground failures, and non-ground failures. Aspects of the required documentation include the field performance, geotechnical conditions, and ground motions. We illustrate these aspects of a typical case history using an example site having both ground failure (liquefaction-induced lateral spreading) and non-ground failure in adjacent areas. As shown in Figure 1, the site is located in Urayasu (Lat: $35.6380^{\circ}$; Long: $139.9335^{\circ}$ ), and the case history is related to performance from the 2011 Tohoku earthquake mainshock.

\subsubsection{Field performance}

Reliable evaluation of field performance requires post-event reconnaissance from a trusted source such as the Geotechnical Extreme Events Reconnaissance (GEER) Association, the Earthquake Engineering Research Institute (EERI), local professional or governmental groups, and/or local university professors and students. The minimal required documentation is a written description of ground failure that occurred at the site and its geographic extent, a description of 
the lack of ground failure (as applicable), the date/time of the observation, and the precise location (with geodetic coordinates) of the observations. Additional useful information includes ground-based photographs, maps of surface features, relatively advanced imaging of surficial features through Light Detection And Ranging (LiDAR) scanning, or post-event images of the site from air photos or satellites. Evidence of ground failure from these data sources may include sediment boils, ground cracks, and deformations of above- or below-ground structures. Liquefaction can be identified as the cause of ground failure when sediment boils are observed. A lack of ground failure is an important observation, but it should be understood that such an observation does not preclude the occurrence of liquefaction or strength loss at depth that is not manifest at the ground surface.

In the case of the Urayasu site, the reconnaissance was performed by GEER [9] and includes information from all of the above-listed sources. Figure 1 distills the essential observations for the purpose of identifying portions of the site with and without ground failure.

\subsubsection{Geotechnical conditions}

A case history of ground failure is only useful for model development if some quantitative evaluation of site conditions is available. All sites listed in the NGL database will have such information. At this time, we anticipate that the minimum required information will include the soil stratigraphy, ground water depth, details pertaining to soil type, and penetration resistance. Ideally, information on the horizontal distribution of these features is also provided; while this information may not always be available, notes on the likely geological heterogeneity made by the field engineer/geologist are useful.

Information on soil type is critical and is an element of site data that is often missing or incomplete. The minimum required information on soil type is tip and sleeve resistance from 
cone penetration test (CPT) soundings or soil classification based on visual inspection or index testing when samples are available. Information related to soil type that significantly increases the value of a case study includes:

- Gradation testing and plasticity tests

- Water content

- Assessments of mechanical behavior of soil through cyclic testing or undrained monotonic testing in combination with consolidation tests (to evaluate the potential for undrained strength normalization).

Penetration resistance testing from CPT is desirable due to the relative standardization of these procedures. In the case of standard penetration testing, energy ratios associated with the hammer lift and drop mechanism should be reported. These energy ratios ideally are based on site- and equipment-specific energy measurements [10], but otherwise can be based on local experience or published values [11,12]. In situ seismic velocity testing will also be included with the geotechnical characterization where available.

At the example Urayasu site, Figure 2 shows results of CPT soundings both in the ground failure/liquefaction zone and outside of the lateral spread. The ground water depth at this location is 1.3 to $1.5 \mathrm{~m}$. The cone data in Figure 2 has been processed and evaluated per recommendations provided in [13] as dimensionless and overburden-normalized penetration resistance $\left(Q_{t n}\right)$ and soil behavior type index $\left(I_{c}\right)$. The site characterization in this case included CPT-based sampling in layers judged to be most critical for ground failure; results of index tests from these samples are shown in Figure 2. The interpretation of this data for identification of the 'critical layer' is deferred to a subsequent section on the NGL flatfile. 


\subsubsection{Ground motion}

For the NGL database, ground motion characterization generally pertains to the intensity of shaking at the ground surface and its uncertainty. The only exception to this is vertical arrays, where ground motions are recorded at depth (a rare circumstance at ground failure case history sites). The evaluation of cyclic stresses at depth given the shaking intensity at the surface is a modeling issue that enters the documentation at the flatfile stage, as described in the next section.

The ground motion intensity measure used for liquefaction analysis is generally the horizontal, median-component (denoted RotD50 [14]) peak ground acceleration (PGA). This parameter is widely used because the product of $P G A$ and total vertical stress at the depth of interest is generally taken as proportional to the peak shear stress imposed by the earthquake at that depth [15]. Additional intensity measures used in some cases are cumulative absolute velocity beyond a $5 \mathrm{~cm} / \mathrm{s}$ threshold $\left(C A V_{5}\right)$, Arias intensity $\left(I_{A}\right)$, and pseudo-spectral accelerations at various oscillator periods. Our remarks here are focused on $P G A$, but additional intensity measures are likely to be included in the database.

We propose the following procedures for estimating median $P G A$ and its associated uncertainty, in order of preference:

1. When a ground motion recording instrument (accelerograph or seismograph) is located at the site of interest or in reasonable proximity, intensity measures from the recording are used, possibly with some correction for the effects of liquefaction on the record, depending on the time at which liquefaction occurred (details in [16]). The uncertainty in this case would be derived solely from uncertainty in the liquefaction correction. An acceptable distance to the accelerograph is admittedly subjective, and should be evaluated in consideration of geological heterogeneity. While this issue 
remains unresolved, it is likely that at separation distances > 50-200 m, ground motions would be developed using approaches (2) or (3) below.

2. When the earthquake event that produced the case history is included in ground motion databases used to derive ground motion predicton equations (GMPE), the natural $\log$ mean intensity measure at the site should be taken as the sum of the GMPE mean (using appropriate site parameters including $V_{S 30}$ and basin depths, or alternatively site terms derived from site-specific analysis), the event term associated with that earthquake and the GMPE, and a mapped within-event residual to correct for spatial variations in path and source effects not captured by the GMPE (this residual is mapped using the simple Kriging method, [17]). This approach, which is explained further in [18], takes into consideration available recordings of the earthquake, while accounting for differences in site conditions among recording sites. The natural log standard deviation applicable to this estimate is associated with the within-event residual term, and varies spatially. For locations near ground motion recording sites, the standard deviation is small; for sites far from instruments, it approaches the within-event standard deviation (generally denoted $\phi_{l n}$ ) from the GMPE. This approach is similar to procedures given previously [19-22], but has distinct features as described by Kwak et al. [18].

3. When recordings are available for the earthquake in question, but the event was not included in the GMPE database, the procedure from (2) can be applied but with the event term set zero. In this case the mapped residuals will likely have a non-zero mean. 
4. When recordings for the event are either not available or are very sparse, GMPE log mean predictions should be used. These estimates are likely to carry a larger degree of uncertainty than those from (1), (2), or (3).

For all three approaches, the GMPE should be appropriate for the tectonic regime that produced the earthquake event [23]. Ground motion estimates from approach (2) will converge to the recorded $P G A$ as the separation distance between an accelerograph and the site approaches zero. For this reason, approaches (1) and (2) provide the same result for sites very near a ground motion recording instrument, aside from the liquefaction correction. In addition to recent case histories, we expect to re-process ground motions for previous case histories in this manner so that demands for all NGL sites are estimated consistently.

For the example Urayasu site, recordings near the site produce a median estimate of $P G A$ $\approx 0.174 \mathrm{~g}$ (using procedure 3 above) with an uncertainty of $\phi_{l n}=0.28$ (natural $\log$ units). The uncertainty estimate is based on semi-variograms by [24], and takes into consideration the separation distance between the site and the nearest ground motion station, which is $0.5 \mathrm{~km}$.

A subset of sites that is being developed in NGL has observations of liquefaction manifest at the surface and ground motion recordings that exhibit evidence of liquefaction effects. Special procedures have been developed to interpret ground motions for these sites, with the goal of identifying conditions at the liquefaction triggering threshold. This important aspect of the NGL project is described further in [16].

\subsection{NGL Flatfile}

The NGL flatfile is envisioned as a synthesis of parameters used for model development. Parameters used in three recent liquefaction triggering models $[5,7,8]$ are shown in Table 1 . The 
NGL flatfile for triggering model development would include these parameters and likely others identified over the course of the project.

The key parameters produced from the flatfile that are used for the development of triggering models are a "reference" cyclic stress ratio (denoted $C S R^{*}$ ) that corresponds to reference conditions of $\sigma_{\mathrm{v} 0}^{\prime}=1 \mathrm{~atm}, \tau_{\text {static }}=0$, and $\mathbf{M}=7.5$, and a parameter representing soil penetration resistance or seismic velocity. Parameter $C S R^{*}$ is computed as (adapted from [12], and others):

$C S R^{*}=0.65 \frac{\sigma_{v}}{\sigma_{v}^{\prime}} \frac{P G A}{g} r_{d} \times \frac{1}{K_{\sigma} K_{\alpha} C_{M}}$

where $\sigma_{v}$ and $\sigma_{v}{ }^{\prime}$ are total and effective stresses at the depth of interest (usually the center of the critical layer), $r_{d}$ is a stress reduction factor to account for the flexibility of the soil column above the depth of interest, $K_{\sigma}$ is an overburden factor to correct the seismic resistance for decreased soil dilatancy as effective stress increases, $K_{\alpha}$ is a shear stress correction factor to account for changes in dilatancy when static, horizontal-plane shear stresses are non-zero, and $C_{M}$ is a magnitude scaling factor to account for the increasing severity of seismic demands as $\mathbf{M}$ increases.

A number of parameters, such as $r_{d}, K_{\sigma}, K_{\alpha}$, and $C_{M}$ are not source data, but are intermediate parameters that characterize particular components of most liquefaction triggering models. As such, these parameters are somewhat subjective and will vary between modelers. Naturally, $C S R^{*}$ as derived from Eq. (1) is then also subjective. This subjectivity may require multiple flatfiles for multiple modeling teams, or at least separate families of parameters within a single flatfile for those teams. The fundamental differentiation of objective data in the NGL database and subjective data in the flatfile is an important element of NGL. 
To illustrate this process, we apply to the Urayasu case history site the $r_{d}, K_{\sigma}, K_{\alpha}$, and $C_{M}$ estimates from [7]. Figure 2 identifies the depth range for the "critical layer." This process of identifying the critical layer is itself subjective. In the present case our judgment is that the base of the critical layer is bound by a non-susceptible (clay) layer. The shallow limit of the critical layer is bound by a dense near-surface layer (non-ground failure location) and by relatively plastic (high $I_{c}$ ) material within the ground failure zone. Table 2 shows the parameters required for flatfile development for these sites both in the ground failure and non-ground failure regions (using CPT-based soil penetration resistance).

Figure 3 shows where the results for the critical layers plot relative to the Boulanger and Idriss [7] probabilistic liquefaction triggering criteria and their data. The uncertainty around the plotted data points in the horizontal and vertical directions are related to dispersion of $P G A$ (vertical direction) and penetration resistance within the critical layer (horizontal direction). The example sites plot near the liquefaction triggering threshold.

\section{NGL Data Collection to Date}

As mentioned in the Section 1, work to date in the NGL project has been directed in part towards developing high-value case histories. In this section, we provide an overview of data collection to date. We describe how sites were selected for geotechnical characterization and the types of tests that were performed. In all cases, the sites selected for characterization activities had prior geotechnical data that was supplemented to fill data gaps in the present work.

\subsection{Japan Sites}

The 2011 M 9.0 Tohoku earthquake produced a wealth of field observations of liquefaction and non-ground failure, including sites with measured ground deformations and measured foundation 
performance [9]. Following extensive discussions at several international workshops among many of the authors of this paper and others with expertise and experience in this area, priorities for site characterization were identified as follows:

1. Sites having well documented lateral ground deformation from traditional mapping and LiDAR imaging.

2. Sites having ground motion instrumentation and well-documented field performance with respect to liquefaction or lack of ground failure. Liquefaction sites with ground motion recordings provide the opportunity to estimate conditions at the liquefaction triggering threshold, as described further in [16].

3. A series of sites on reclaimed land areas in Mihama-ward, Chiba Prefecture. The fill materials in these areas were placed hydraulically.

4. Vertical ground motion array sites, many operated by the Port and Airport Research Institute, where varying levels of ground failure were observed.

5. Non-ground failure sites poorly explained by current methods for liquefaction susceptibility and triggering assessment.

Based on the above criteria, seven sites were investigated in the first phase of data collection (completed in April-July 2014) and four sites were investigated in the second phase (completed in September-October 2015) as shown in Figure 4. One site was selected per the first criterion (lateral ground deformation), nine were selected per the second, fourth, and/or fifth criteria (all near accelerographs, including two vertical arrays), and one was selected per the third criterion (Mihama-ward). Table 3 lists the sites and attributes that led to their selection. Testing at the sites included CPT (including sampling), borings with sampling include SPTs with energy 
measurements, tube sampling for advanced laboratory tests (i.e., consolidation and undrained monotonic triaxial tests), and shear wave velocity measurements using surface wave methods.

\subsubsection{Lateral Spread at Urayasu City}

The ground failure and non-ground failure example described in the Section 3.1 (Figures 1-3) is from the Urayasu lateral spread site. Figure 5 is a plan view of the spread feature, showing displacement vectors of up to $2.8 \mathrm{~m}$ horizontally towards the sea $(1.0 \mathrm{~m}$ of subsidence also occurred). The width of the spread feature is about $600 \mathrm{~m}$. The spreading occurred in hydraulic fill on an average slope of about 3\%. Although a free-face is located below the spread feature, it did not participate in the spread because a pile-supported quay wall stabilized the free-face.

Site performance was first documented by the GEER reconnaissance team using field mapping and photography. A subsequent phase of work in the GEER reconnaissance imaged ground morphology using terrestrial LiDAR. Both the field mapping and LiDAR imaging were used to evaluate displacement vectors and to support the development of the site plan in Figure 5. We performed four CPTs, one boring with SPT, and four SASWs to evaluate subsurface conditions inside and outside of the deformation zone. There are also four pre-existing boring logs performed in the 1970s to 1990s, which are available from Chiba Prefecture [25].

Four other lateral spread sites have similar levels of mapping but lack geotechnical data. This data may be compiled in future work. The inventory of data from these sites is useful both for triggering and semi-empirical lateral spread models.

\subsubsection{Strong Ground Motion Stations}

Observations of liquefaction and non-ground failure in the vicinity of accelerograph stations are especially valuable for model building, because the seismic demands at these sites have significantly less uncertainty than those for sites where ground motions are estimated. For this 
reason, GEER reconnaissance activities emphasized locations near accelerographs [9]. Resulting observations and preliminary analyses of these conditions are provided by [26] for 22 liquefaction sites and 16 non-ground failure sites that are mostly located in the greater Tokyo Bay region of Japan.

Many of the accelerograph sites for which field performance and ground motion information are available also have some geotechnical data. For example, accelerographs within the K-NET network [27] have boring logs, SPT $N$-values, and $V_{S}$ profiles that typically extend to 10-20 m depth. A similar format is used for accelerographs in the PARI network [28], except that borehole depths are variable. Boring logs and $V s$ profiles are available for KiK-net vertical array sites that extend to considerably larger depths. As described by [26], there are several complications in the use of geotechnical data from these arrays, including lack of quantitative soil type information (from laboratory tests), unknown SPT energy levels, which are particularly variable at K-NET and PARI sites [29], and limited spatial resolution of velocity data. Our site characterization was motivated in large part by a need to fill these data gaps. As shown in Table 3, we investigated seven K-NET sites, one PARI site, and one site maintained by the Tokyo Metropolitan Government site (Shinariake).

Among the eight K-NET and PARI sites, three (CHB005, Chiba-g, TKY013) had no observable ground failure, despite low penetration resistance, shallow ground water, and the presence of silty soils. An important issue in these cases is whether those fine-grained materials are liquefaction-susceptible. Site CHB024 had severe liquefaction, and was investigated to support NGL-related activities to identify $C S R^{*}$-penetration resistance conditions at the liquefaction triggering threshold [16]. Site TKY017 had moderate liquefaction and was investigated for similar reasons. Site IBR014 had minor liquefaction, apparently involving a deep 
liquefiable layer $(\sim 20 \mathrm{~m})$. Two sites investigated in the Sendai area had experienced highamplitude shaking; MYG013 experienced PGA > 1.0g and had moderate liquefaction involving a medium dense sandy and silty gravel layer, while MYG010 experienced PGA > 0.4g and had moderate liquefaction on a medium to dense sand layer.

We performed CPTs for each investigated site, and SPTs for CHB005, Chiba-g, IBR014, and MYG013. An objective of the SPTs at K-NET and PARI stations was to investigate energy ratios for SPT $N$-values reported in the logs. Hammer energy ratios were recorded using equipment and analysis procedures [10]; comparison of these results to those for adjacent $\mathrm{K}$ NET and PARI logs suggest SPT efficiencies from that prior work that are both larger and smaller than the U.S. standard of $60 \%$. This suggests a lack of uniformity in field testing procedures and/or equipment. Laboratory index tests for specimens from SPT samplers and CPT samplers were also performed.

Three sites in Tokyo (Sunamachi, Tatsumi, and Shinariake) are located in the vicinity of ground motion stations (K-NET and Tokyo Metropolitan Government, TMG) and have instrumentation to record ground settlement and ground water table fluctuation measurements [30]. We performed exploration at the Shinariake site, which has a downhole array with four seismographs at $2,16,36$, and $75 \mathrm{~m}$ depth in addition to the ground water elevation and settlement instruments. This site experienced settlement but had no other surface manifestation of liquefaction.

As indicated in Table 3 as site-to-exploration distance, there are cases in which borings and CPTs were not co-located with accelerographs. This resulted from inabilities to secure necessary site access for field work in some cases. 


\subsubsection{Mihama-Ward (reclaimed land by hydraulic fill)}

Mihama-ward in Chiba, Japan is constructed on reclaimed land that was developed using hydraulic fill procedures in the mid-1970s [31]. As shown in Figure 6, locations of discharge pipes are well known, which is useful because during hydraulic filling relatively fast flow velocities are expected near discharge locations (producing relatively coarse sediments) whereas slower velocities in intermediate areas would be expected to produce relatively fine-grained sediments. The variable composition of these materials is of considerable interest from a liquefaction susceptibility perspective.

After the Tohoku event, extensive reconnaissance of reclaimed land areas in Mihamaward was conducted by Chiba University as well as several government agencies. The Chiba University reconnaissance, documented by Sekiguchi and Nakai [31], mapped the surface manifestation of liquefaction according to three levels: 1) Heavy liquefaction: "The overflow area of the sand boiling found in the spot is more than about $1 \mathrm{~m}$ "; 2) Minor liquefaction: "The overflow area is less than about 1 m"; 3 ) no liquefaction: "No sand boiling was found."

There is a general correlation between field performance and discharge pipe locations with liquefaction being most concentrated near discharge pipes and intermediate areas having non-ground failure. Our work in this region has the objective of identifying soil compositional factors that contribute to varying levels of liquefaction severity. Many borings and a small number of CPTs have already been performed in the area (including the nine CPTs shown in Figure 6). NGL has contributed to this effort by targeted sampling of soils from presumed critical layers in liquefaction, marginal, and non-ground failure areas. Results of this testing are being compared to traditional susceptibility criteria [32,33] and inferences of soil behavior derived from more advanced testing (consolidation, triaxial undrained monotonic and cyclic shear). 


\subsection{New Zealand Sites}

Following the 2010-2011 Canterbury Earthquake Sequence (CES), several engineers and researchers conducted field studies in Christchurch, New Zealand to characterize subsurface conditions at sites that either had surface manifestation of liquefaction or no observed ground failure. Over 22,000 CPT soundings and over 4,500 soil exploratory borings have been performed since the CES making this dataset incredibly valuable, especially considering that each site was shaken multiple times by major earthquake events (four of which had $\mathbf{M}>5.9$ ).

Post-earthquake reconnaissance efforts were conducted by several organizations, including government agencies, private consultancies, academic research institutions, and volunteer engineers and geologists. The Earthquake Commission, Tonkin + Taylor, and the University of Canterbury facilitated many of these efforts. Among the four events, the best reconnaissance documentation is for the 4 September 2010 Darfield (M 7.1) and 22 February 2011 Christchurch (M 6.2) earthquakes. This documentation includes reports by the National Science Foundation (NSF)-sponsored Geotechnical Extreme Events Reconnaissance (GEER) Association. The observations contained in these reports have been incorporated in the Canterbury Geotechnical Database maps, showing available post-earthquake observations throughout the Canterbury region for each of the four major earthquake events.

The NGL New Zealand dataset focuses on pulling together a select number of the most insightful case histories from four well-documented geotechnical projects, the earliest beginning in 2011 and the most recent continuing today. Combining the resources of international, governmental, and private organizations, along with researchers from a diverse range of backgrounds, these projects represent a significant contribution to the global dataset in development of the next generation liquefaction assessment procedures. While the projects are 
individually detailed in separate publications, their case history data are being standardized and compiled for incorporation in the NGL database.

Canterbury, New Zealand subsurface geotechnical data were gathered from four projects summarized in Table 4, which collectively investigated the site locations shown in Figure 7. All sites within the dataset contain CPT data, with sonic boring, laboratory testing data, and shear wave velocity profiles available for many of the sites. Case histories at these sites are based on ground failure observations from the 2010-2011 Canterbury Earthquake Sequence and cover a broad spectrum of liquefaction effects, ranging from no observation to severe damage.

The New Zealand sites to be included in the NGL database are summarized in the following sections. Each project was led by researchers and engineers who were on the ground during the post-earthquake reconnaissance, bringing first-hand observations and expert knowledge to the case history analysis. The case histories included in these projects were selected for being comprehensive, vetted investigations with high-quality detailed data out of the quantity available in the Canterbury Geotechnical Database.

\subsubsection{NSF-PEER-MBIE-EQC Liquefaction Triggering \& Consequence for Low-Plasticity Silty Soils}

The silty soils project will contribute eight sites to the NGL database. Each site has a minimum of one CPT sounding, a sonic boring with disturbed bulk samples, a mud rotary cased boring with undisturbed sampling, and crosshole seismic testing. Sites were selected based on the presence of silty soils in the upper few meters and comparisons of observed vs. predicted liquefaction for the September 2010 Darfield earthquake and the February 2011 Christchurch earthquake, with an emphasis on sites in which prevalent liquefaction triggering and ground settlement procedures over-predicted the observed performance. 
Beyzaei et al. [34] and Stringer et al. [35] provide detailed information on the laboratory testing program for two of the sites investigated as part of the silty soils project. Cyclic triaxial laboratory testing data, Atterberg limits, and particle size analysis are presented in addition to the field work and pre-existing data summaries.

As the most recent of the four NGL New Zealand projects, the silty soils project includes direct support from NGL funding towards the field work and laboratory testing program. The three additional projects listed below were independently funded, but are being standardized and incorporated in the NGL database through the support of NGL funding.

\subsubsection{NSF-EQC CBD Project}

The Central Business District (CBD) of Christchurch project will contribute eight sites to the NGL database. Each site has at least one CPT sounding and at least one mud rotary cased boring with undisturbed sampling. Cyclic triaxial laboratory testing data, Atterberg limits, and particle size analysis are available in addition to the field work. Sites were selected based on observed building damage, covering varying degrees of damage due to global settlement and differential settlement. Significant amounts of silty sand are present in the upper few meters at some sites. An additional three sites from the CBD project are also being considered for incorporation in the NGL database, to cover instances of non-liquefaction within the CBD. Several studies [36, 37, 38] developed the data for this work.

\subsubsection{Tonkin + Taylor Liquefaction Vulnerability Study}

The T\&T study will contribute twelve sites to the NGL database. Each site has one CPT sounding and one nearby soil boring with sampling. Fines content data are available for the soil borings. Sites were selected by Tonkin \& Taylor to evaluate differences between CPT-based and 
SPT-based liquefaction triggering procedures, quantifying vulnerability to liquefaction-related damage beyond typical settlement estimates [39].

\subsubsection{Virginia Tech \& Univ. of Canterbury \& Others Liquefaction Triggering Study}

The VT-UC study will contribute twenty-five sites to the NGL database. Each site has one CPT sounding and SASW/MASW testing, as described in [40]. With the goal of investigating sites that exhibited differing liquefaction behavior during the Darfield and Christchurch earthquakes, the authors state that they:

... selected 25 sites to analyze in detail, many of which had minor surficial liquefaction manifestations resulting from the Darfield or Christchurch earthquake. The sites were evaluated during both these events, resulting in 50 high-quality case histories. The sites selected for detailed evaluation were located relatively close to strong ground motion stations and were characterized by both CPT soundings and surface wave testing.

\section{Role of Supporting Studies}

We envision the NGL liquefaction susceptibility, triggering, and effects models as being 'semiempirical', meaning that both empirical data analysis and results of supporting studies will be considered (to varying degrees) in model development. Supporting studies are needed to examine specific technical issues that are essential for model development but which cannot be resolved solely on the basis of empirical data, even after the database is expanded in the manner described above.

Some of the topics to be considered by such teams are envisioned to include liquefaction at large depth, pore pressure generation and strength loss in soils having high fines content and intermediate levels of plasticity, effects of fines content and plasticity on penetration resistance, 
liquefaction of gravels, age effects on liquefaction resistance, potentially increased liquefaction resistance of thin soil layers near drainage boundaries (or the upper portion of relatively thick layers near the boundary), and volume change/shear deformations of soils having variable levels of density, fines content, and overburden stress. Some of these issues can be addressed by highquality laboratory tests; centrifuge or large shake table model testing may also be used to resolve others. Still others may be addressed with numerical modeling of problems that employ wellcalibrated constitutive models. Table 5 lists several topics that have been identified in international workshops, provides a brief explanation of the technical issues, and cites examples of prior work in the subject area.

For each of these technical issues, our approach will be to evaluate work to date on the subject, identify further research needs to further develop understanding of the issue so that it can be modeled, support projects to develop this understanding, and ultimately incorporate appropriate representations of the effect in NGL models.

Table 5 only pertains to liquefaction triggering models. Supporting studies will also likely be needed for a range of issues related to liquefaction effects, including ground settlement, structure settlement, post-liquefaction shear strength, and lateral spreading.

\section{Anticipated Products and Next Steps}

As with prior NGA projects for ground motions, the NGL project deliverables are anticipated to consist of data resources and engineering predictive models. The data resources will include the NGL database and flatfiles, as described previously. The liquefaction models will consist of probabilistic models for liquefaction susceptibility, triggering, and effects. The liquefaction triggering models will consist of equations for the limit state function representing the boundary 
between liquefaction and non-ground failure. The liquefaction effects models will enable computations of free-field settlements, foundation settlements, free-field displacements from lateral spreading, and post-liquefaction liquefied shear strength.

Because liquefaction and ground failure analyses are routine in engineering practice and are of great practical importance, we anticipate the development of guidelines documents for application, likely tailored to needs of various agencies (e.g., Nuclear Regulatory Commission, state Departments of Transportation, U.S. Army Corps of Engineers).

NGL at present a concept that enjoys broad community support, but which is not yet fully launched due to pending funding commitments. Work to date has largely consisted of compilation of high-value data as described in this paper and the holding of workshops to develop the project vision and plan. We anticipate future growth in the project scope and activity.

\section{Acknowledgments}

Seed funding for NGL was provided by the Pacific Earthquake Engineering Research Center under multi-campus agreement 1117-NCTRSJ. This funding has supported to date seven workshops in which the NGL research project framework was developed, as well as the Japan site characterization work, and database development. Japan reconnaissance activities following the 2011 Tohoku earthquake was provided by GEER - Geotechnical Extreme Event Reconnaissance association. GEER is supported by the NSF under grant \#CMMI-00323914.

Financial support for New Zealand (NZ) researchers for the studies outlined in this paper was provided by the Earthquake Commission (EQC), Ministry of Business, Innovation \& Employment (MBIE), Natural Hazards Research Platform (NHRP), and University of 
Canterbury (UC). The Canterbury Geotechnical Database (CGD), a primary source for NZ field data, was made possible through the support of the NZ Government and contributions from professional engineering companies involved in the recovery of Christchurch (including Tonkin+Taylor), scientific and academic institutions, the Earthquake Commission, councils and insurers. Primary support for U.S. researchers was provided by grants from the U.S. National Science Foundation (NSF) through grants CMMI-1266418, CMMI-1332501, CMMI-1306261, CMMI-1407364, EAPSI-1414671, the U.S. Geological Survey through G12AP20034, and the Pacific Earthquake Engineering Research (PEER) Center through grant NC3KT101114. In association with NSF grant EAPSI-1414671, part of the NZ work was supported by NZ government funding as administered by the Royal Society of New Zealand through the EAPSI program. The Faculty Chair in Earthquake Engineering Excellence at UC Berkeley (UCB) provided partial support for the NZ field sampling and lab testing activities. Any opinions, findings, and conclusions or recommendations expressed in this material are those of the authors and do not necessarily reflect the views of MBIE, EQC, NSF, USGS, or PEER. Several other organizations and individuals contributed to the development of the NZ data, and their contributions are acknowledged in the papers referenced in this study. 


\section{References:}

[1] National Academies. State of the art and practice in earthquake induced soil liquefaction assessment (assessed 2016 Feb). Available from: https://www8.nationalacademies.org/cp/projectview.aspx?key=49573.

[2] Power M, Chiou BSJ, Abrahamson NA, Bozorgnia Y, Shantz T, Roblee C. An overview of the NGA project. Earthq Spectra 2008;24:3-21.

[3] Bozorgnia Y, Abrahamson NA, Al Atik L, Ancheta TD, Atkinson GM, Baker JW, et al. NGA-West2 research project. Earthq Spectra 2014;30:973-87.

[4] Cetin KO, Seed RB, Moss RES, Der Kiureghian A, Tokimatsu K, Harder LF Jr, et al. Field performance case histories for SPT-based evaluation of soil liquefaction triggering hazard. Berkeley (CA): University of California, Berkeley; 2000. Geotechnical Engineering Research Report No. UCB/GT-2000/09.

[5] Boulanger RW, Wilson DW, Idriss IM. Examination and reevalaution of SPT-based liquefaction triggering case histories. J Geotech Geoenv Eng 2012;138:898-909.

[6] Moss RES, Seed RB, Kayen RE, Stewart JP, Youd TL, Tokimatsu K. Field case histories for CPT-based in situ liquefaction potential evaluation. Berkeley (CA): University of California, Berkeley; 2003. Geoengineering Research Report No. UCB/GE-2003/04.

[7] Boulanger RW, Idriss IM. CPT and SPT based liquefaction triggering procedures. Davis (CA): University of California, Davis; 2014. Center for geotechnical modeling Report No. UCD/CGM-14/01.

[8] Kayen R, Moss RES, Thompson EM, Seed RB, Cetin KO, Der Kiureghian A, et al. Shearwave velocity-based probabilistic and deterministic assessment of seismic soil liquefaction potential. J Geotech Geoenv Eng 2013;139:407-19.

[9] Ashford SA, Boulanger RW, Donahue JL, Stewart JP. Geotechnical quick report on the Kanto plain region during the March 11, 2011, Off Pacific Coast of Tohoku Earthquake, Japan. Geotechnical Extreme Events Reconnaissance; 2011. GEER Association Report No. GEER-025a.

[10] Abou-Matar H, Goble G. SPT dynamic analysis and measurements. J Geotech Geoenv Eng 1997;123:921-8.

[11] Youd TL, Idriss IM, Andrus RD, Arango I, Castro G, Christian JT, et al. Liquefaction resistance of soils: summary report from the 1996 NCEER and 1998 NCEER/NSF workshops on evaluation of liquefaction resistance of soils. J Geotech Geoenv Eng 2001;127:817-33.

[12] Cetin KO, Seed RB, Der Kiureghian A, Tokimatsu K, Harder LF Jr, Kayen RE, et al. Standard penetration test-based probabilistic and deterministic assessment of seismic soil liquefaction potential. J Geotech Geoenv Eng 2004;130:1314-40.

[13] Robertson PK. Interpretation of in-situ tests - some insights. ISC'4: J.K. Mitchell lecture; 2012; Brazil.

[14] Boore DM. Orientation-independent, nongeometric-mean measures of seismic intensity 
from two horizontal components of motion. Bull Seismol Soc Am 2010;100:1830-5.

[15] Seed HB, Idriss IM. Simplified procedure for evaluating soil liquefaction potential. J Soil Mech Found Div 1971;97:1249-73.

[16] Kramer SL, Sideras SS, Greenfield MW. The timing of liquefaction and its utility in liquefaction hazard evaluation. Proceedings of 6th International Conference on Earthquake Geotechnical Engineering; 2015 Oct 1-4; Christchurch, New Zealand. Paper No.: 379.

[17] Cressie N. Statistics for spatial data. Revised ed. New Jersey: Wiley; 2015.

[18] Kwak DY, Stewart JP, Brandenberg SJ, Mikami A. Characterization of seismic levee fragility using field performance data. Earthq Spectra. In press 2016. doi:10.1193/030414EQS035M

[19] Wald DJ, Worden BC, Quitoriano V, Pankow KL. ShakeMap manual: technical manual, user's guide, and software guide. U.S. Geological Survey; 2005. 132 p.

[20] Yamazaki F, Motomura H, Hamada T. Damage assessment of expressway networks in Japan based on seismic monitoring. Proceedings of 12th World Conference on Earthquake Engineering; 2000 Jan 30-Feb 4; Auckland, New Zealand. New Zealand: Upper Hutt; 2000.

[21] Sawada S, Suetomi I, Fukushima Y, Goto H. Characteristics and distribution of strong ground motion during the 2004 Niigata-ken Chuetsu and 2007 Niigata-ken Chuetsu-oki Earthquake in Japan. Proceedings of the 14th World Conference on Earthquake Engineering; 2008 Oct 12-17; Beijing, China.

[22] Bradley BA. Site-specific and spatially-distributed ground-motion intensity estimation in the 2010-2011 Canterbury earthquakes. Soil Dyn Earthq Eng 2014;61:83-91.

[23] Stewart JP, Douglas J, Javanbarg M, Bozorgnia Y, Abrahamson NA, Boore DM, et al. Selection of ground motion prediction equations for the Global Earthquake Model. Earthq Spectra 2015;31:19-45.

[24] Jayaram N, Baker JW. Correlation model for spatially distributed ground-motion intensities. Earthq Eng Struct Dyn 2009;38:1687-708.

[25] Chiba Prefecture. Chiba Prefecture Geology and Environment Information Bank (assessed 2015 Jun). Available from: https://www.pref.chiba.lg.jp/suiho/chishitsu.html (in Japanese).

[26] Cox BR et al. Liquefaction at strong motion stations and in Urayasu City during the 2011 Tohoku-Oki Earthquake. Earthq Spectra 2013;29:S55-S80.

[27] Kinoshita S. Kyoshin Net (K-NET). Seismol Res Lett 1998;69:309-32.

[28] Port and Airport Research Institute (PARI). Seismic network for ports (assessed 2015 Jun). Available from: http://www.eq.pari.go.jp/kyosin/ (in Japanese).

[29] Kwak DY, Brandenberg SJ, Mikami A, Stewart JP. Prediction equations for estimating shear-wave velocity from combined geotechnical and geomorphic indexes based on Japanese data set. Bull Seismol Soc Am 2015;105:1919-30.

[30] Tokyo Metropolitan Government (TMG). 2011 observation results for ground settlement and ground water table at Tokyo port. Internal report for Tokyo Metropolitan Government; 2011. 
[31] Sekiguchi T, Nakai S. Effects of local site conditions on liquefaction damage in Mihama Ward of Chiba City. Proceedings of the International Symposium on Engineering Lessons Learned from the 2011 Great East Japan Earthquake; 2012 Mar 1-4; Tokyo, Japan

[32] Boulanger RW, Idriss IM. Liquefaction susceptibility criteria for silts and clays. J Geotech Geoenv Eng 2006;132:1413-26.

[33] Bray JD, Sancio RB. Assessment of the liquefaction susceptibility of fine-grained soils. J Geotech Geoenv Eng 2006;132:1165-77.

[34] Beyzaei CZ, Bray JD, Cubrinovski M, Riemer M, Stringer ME, Jacka M, et al. Liquefaction resistance of silty soils at the Riccarton road site, Christchurch, New Zealand. Proceedings of 6th International Conference on Earthquake Geotechnical Engineering; 2015 Nov 1-4; Christchurch, New Zealand. Paper No. 616.

[35] Stringer ME, Beyzaei CZ, Cubrinovski M, Bray JD, Riemer M, Jacka M, et al. Liquefaction characteristics of Christchurch silty soils: Gainsborough Reserve. Proceedings of 6th International Conference on Earthquake Geotechnical Engineering; 2015 Nov 1-4; Christchurch, New Zealand. Paper No. 726

[36] Bray, J.D., Cubrinovski, M., Zupan, J., and Taylor, M. Liquefaction effects on buildings in the Central Business District of Christchurch. Earthq. Spectra 2014a, 30(1):85-109.

[37] Taylor, M., Cubrinovski, M., and Bradley, B. 2012. Characterisation of ground conditions in the Christchurch central business district. Australian Geomechanics Journal 47(4): 43-58.

[38] Bray, J.D., Markham, C.S., and Cubrinovski, M. 2015. Liquefaction assessments in the Central Business District of Christchurch, New Zealand. Proc. of the $6^{\text {th }}$ International Conference on Earthquake Geotechnical Engineering, 1-4 Nov., Christchurch, New Zealand, Paper No. 791.

[39] Tonkin and Taylor. Liquefaction Vulnerability Study. Earthquake Commission (EQC); 2013. T\&T Report: 52020.0200/v1.0, 52 p.

[40] Green RA, Cubrinovski M, Cox B, Wood C, Wotherspoon L, Bradley B, et al. Select liquefaction case histories from the 2010-2011 Canterbury earthquake sequence. Earthq Spectra 2014; 30:131-53.

[41] University of California, Berkeley and University of Canterbury. Liquefaction triggering \& consequence for low-plasticity silty soils: Conventional wisdom vs. the Canterbury experience. Data reports prepared for the NZ Ministry of Business, Innovation \& Employment, submitted to Tonkin and Taylor, 2015 (to be published).

[42] Markham CS, Bray JD, Riemer MF, Cubrinovski M. Characterization of shallow soils in the Central Business District of Christchurch, New Zealand. ASTM Geotechnical Testing Journal 2015 (under review).

[43] Idriss IM. An update to the Seed-Idriss simplified procedure for evaluating liquefaction potential. Proceedings of TRB Workshop on New Approaches to Liquefaction; Federal Highway Administration; 1999 Jan. Publication No. FHWA- RD-99-165.

[44] Kishida T, Boulanger RW, Abrahamson NA, Driller MW, Wehling TM. Seismic response of levees in Sacramento-San Joaquin Delta. Earthq Spectra 2009;25:557-82. 
[45] Boulanger RW. Relating $\mathrm{K}_{\alpha}$ to relative state parameter index. J Geotech Geoenv Eng 2003;129:770-3.

[46] Montgomery J, Boulanger RW, Harder, LF, Jr. Examination of the $\mathrm{K}_{\sigma}$ overburden correction factor on liquefaction resistance. J Geotech Geoenv Eng 2014;140,04014066:1-11.

[47] Carraro JAH, Bandini P, Salgado R. Liquefaction resistance of clean and nonplastic silty sands based on cone penetration resistance. J Geotech Geoenv Eng 2003;129:965-76.

[48] Polito CP. Martin II, JR. Effects of nonplastic fines on the liquefaction resistance of sands. J Geotech Geoenv Eng 2001;127:408-15.

[49]Leon E, Gassman SL, Talwani P. Accounting for soil aging when assessing liquefaction potential. J Geotech Geoenv Eng 2006;132:363-77.

[50] Hayati H, Andrus R. Updated liquefaction resistance correction factors for aged sands. J Geotech Geoenv Eng 2009;135:1683-92.

[51] Andrus R, Hayati H, Mohanan N. Correcting liquefaction resistance for aged sands using measured to estimated velocity ratio. J Geotech Geoenv Eng 2009;135:735-44.

[52] Maurer BW, Green RA, Cubrinovski M, Bradley BA. Assessment of aging correction factors for liquefaction resistance at sites of recurrent liquefaction. Proceedings of the $10^{\text {th }}$ U.S. National Conference on Earthquake Engineering; 2014 Jul 21-25; Anchorage, AK. Earthquake Engineering Research Institute; 2014.

[53] Boulanger RW. High overburden stress effects in liquefaction analyses. J Geotech Geoenv Eng 2003;129:1071-82. 
Tables:

Table 1. List of parameters used in three recent liquefaction triggering models.

\begin{tabular}{|c|c|c|c|}
\hline \begin{tabular}{|c|} 
\\
Parameters
\end{tabular} & \begin{tabular}{|c|} 
Boulanger et al., \\
2012 [5] (SPT)
\end{tabular} & \begin{tabular}{|l|} 
Boul. \& Idriss, \\
2014 [7] (CPT) \\
\end{tabular} & $\begin{array}{l}\text { Kayen et al., } \\
2013[8]\left(V_{s}\right)\end{array}$ \\
\hline \multicolumn{4}{|l|}{ Fundamental Parameters } \\
\hline Moment magnitude, $\mathbf{M}$ & - & - & - \\
\hline Peak ground acceleration, $P G A$ & $\bullet$ & $\bullet$ & - \\
\hline Liquefaction manifestation & $\bullet$ & $\bullet$ & $\bullet$ \\
\hline Average depth to critical layer & - & - & - \\
\hline Depth to ground water table & $\bullet$ & $\bullet$ & $\bullet$ \\
\hline \multicolumn{4}{|l|}{ Unit weight, $\gamma$} \\
\hline \multicolumn{4}{|l|}{ Static shear stress on horizontal plane, $\tau_{h v}$} \\
\hline Fines content, $F C$ & - & - & \\
\hline CPT tip resistance, $q_{c}$ & & - & \\
\hline CPT sleeve friction, $f_{s}$ & & - & \\
\hline SPT blow count, $N$ & - & & \\
\hline SPT energy ratio (if measured) & - & & \\
\hline Shear wave velocity, $V_{s}$ & & & - \\
\hline \multicolumn{4}{|l|}{ Intermediate or Derived Parameters } \\
\hline Total vertical stress, $\sigma_{v}$ & $\bullet$ & - & $\bullet$ \\
\hline Effective vertical stress, $\sigma_{v}{ }^{\prime}$ & $\bullet$ & $\bullet$ & - \\
\hline Shear stress reduction factor, $r_{d}$ & - & - & - \\
\hline Earthquake-induced cyclic stress ratio, $C S R$ & - & - & - \\
\hline Overburden correction factor, $K_{\sigma}$ & - & - & \\
\hline \multicolumn{4}{|l|}{ Shear stress correction factor, $K_{\alpha}$} \\
\hline Magnitude scaling factor, $C_{M}$ & $\bullet$ & $\bullet$ & - \\
\hline$C S R$ for $\mathbf{M}=7.5, \sigma_{v}^{\prime}=1 \mathrm{~atm}$, and $\alpha=0, \operatorname{CSR}^{*}$ & $\bullet$ & $\bullet$ & $\bullet$ \\
\hline Exponent for overburden normalization, $n$ & & $\bullet$ & \\
\hline Soil behavior type index, $I_{c}$ & & $\bullet$ & \\
\hline Overburden correction factor, $C_{N}$ & - & - & - \\
\hline Overburden-normalized tip resistance, $Q_{t n}$ and $q_{c l N}$ & & - & \\
\hline Overburden-normalized sleeve friction, $F$ & & - & \\
\hline Friction ratio, $F_{r}$ & & - & \\
\hline SPT energy ratio (if inferred) & - & & \\
\hline Energy- and overburden stress-corrected blow count, $\left(N_{l}\right)_{60}$ & • & & \\
\hline Normalized shear wave velocity, $V_{s l}$ & & & - \\
\hline Equivalent clean-sand tip resistance, $q_{c l N c s}$ & & - & \\
\hline Equivalent clean-sand corrected blow count, $\left(N_{1}\right)_{60 c s}$ & • & & \\
\hline
\end{tabular}


Table 2. Parameters for liquefaction triggering analysis for non-ground failure (CPT02) and ground failure (CPT03) locations at example site. Derived parameters from [7].

\begin{tabular}{|c|c|c|c|c|c|c|c|c|c|c|c|c|c|}
\hline & $\mathbf{M}$ & $\begin{array}{c}P G A \\
(\mathrm{~g})\end{array}$ & $\begin{array}{c}\text { Critical } \\
\text { Interval } \\
(\mathrm{m})\end{array}$ & $\begin{array}{c}\text { Avg. } \\
\text { Depth } \\
(\mathrm{m})\end{array}$ & $\begin{array}{c}\text { GWT } \\
\text { Depth } \\
(\mathrm{m})\end{array}$ & $\begin{array}{c}\sigma_{v} \\
(\mathrm{kPa})\end{array}$ & $\begin{array}{c}\sigma_{v}{ }^{\prime} \\
(\mathrm{kPa})\end{array}$ & $r_{d}$ & $\mathrm{CSR}$ & $K_{\sigma}$ & $K_{\alpha}$ & $C_{M}$ & $C^{*} R^{*}$ \\
\hline CPT02 & 9 & 0.174 & $3.0-4.5$ & 3.75 & 1.27 & 67.5 & 43.2 & 1.0 & 0.177 & 1.08 & 1 & 0.916 & 0.178 \\
\hline CPT03 & 9 & 0.174 & $2.5-5.0$ & 3.75 & 1.51 & 67.5 & 45.5 & 1.0 & 0.168 & 1.07 & 1 & 0.939 & 0.167 \\
\hline & $\begin{array}{c}\mathrm{FC} \\
(\%)\end{array}$ & $\begin{array}{c}\mathrm{q}_{\mathrm{c}} \\
(\mathrm{MPa})\end{array}$ & $\begin{array}{c}\mathrm{f}_{\mathrm{s}} \\
(\mathrm{MPa})\end{array}$ & $\begin{array}{c}\mathrm{f}_{\mathrm{r}} \\
(\%)\end{array}$ & $\mathrm{Q}$ & $\mathrm{n}$ & $\mathrm{F}$ & $\mathrm{I}_{\mathrm{c}}$ & $\mathrm{C}_{\mathrm{N}}$ & $\mathrm{q}_{\mathrm{c} 1 \mathrm{~N}}$ & $\Delta \mathrm{q}_{\mathrm{c} 1 \mathrm{~N}}$ & $\mathrm{q}_{\mathrm{c} 1 \mathrm{Ncs}}$ & $\begin{array}{c}\text { CRR } \\
\left(\mathrm{P}_{\mathrm{L}}=15 \%\right)\end{array}$ \\
\hline CPT02 & 14.4 & 4.41 & 0.046 & 1.04 & 65.7 & 0.5 & 1.06 & 2.07 & 1.57 & 68.3 & 18.7 & 87.1 & 0.123 \\
\hline CPT03 & 18.1 & 2.82 & 0.022 & 0.77 & 40.6 & 0.5 & 0.78 & 2.17 & 1.58 & 44.1 & 25.5 & 69.7 & 0.107 \\
\hline
\end{tabular}


Table 3. List of sites in Japan characterized to date from NGL project.

\begin{tabular}{|c|c|c|c|c|c|c|c|}
\hline Location & Tests & Latitude & Longitude & $\begin{array}{l}\text { Nearest } \\
\text { Station }\end{array}$ & $\begin{array}{l}\text { PGA (g) at } \\
\text { N.S. }\end{array}$ & $\begin{array}{c}\text { Site-to- } \\
\text { exploration } \\
\text { distance }(\mathbf{k m})\end{array}$ & $\begin{array}{c}\text { Ground failure } \\
\text { observation }\end{array}$ \\
\hline \multirow{4}{*}{$\begin{array}{l}\text { Urayasu, } \\
\text { Chiba }\end{array}$} & $\begin{array}{l}\text { CPT / } \\
\text { SASW }\end{array}$ & 35.63692 & 139.93215 & $\begin{array}{c}\text { HND } \\
\text { /Keiyo Gas }\end{array}$ & 0.174 & 0.61 & \multirow{4}{*}{ Lateral spread } \\
\hline & \begin{tabular}{|c|} 
SPT / CPT / \\
SASW \\
\end{tabular} & 35.63802 & 139.93352 & $\begin{array}{c}\text { HND } \\
\text { /Keiyo Gas }\end{array}$ & 0.174 & 0.54 & \\
\hline & \begin{tabular}{|c|}
$\mathrm{CPT} /$ \\
$\mathrm{SASW}$ \\
\end{tabular} & 35.63793 & 139.93356 & $\begin{array}{c}\text { HND } \\
\text { /Keiyo Gas }\end{array}$ & 0.174 & 0.54 & \\
\hline & $\begin{array}{l}\text { CPT / } \\
\text { SASW }\end{array}$ & 35.64029 & 139.93828 & $\begin{array}{c}\text { HND } \\
\text { /Keiyo Gas }\end{array}$ & 0.174 & 0.73 & \\
\hline $\begin{array}{c}\text { Choshi, } \\
\text { Chiba }\end{array}$ & \begin{tabular}{|c|} 
SPT / CPT / \\
SASW
\end{tabular} & 35.73536 & 140.82732 & $\begin{array}{l}\text { CHB005 } \\
\text { /K-NET }\end{array}$ & 0.179 & 0.02 & $\begin{array}{l}\text { No ground } \\
\text { failure }\end{array}$ \\
\hline $\begin{array}{l}\text { Chuo, } \\
\text { Chiba }\end{array}$ & \begin{tabular}{|c|} 
SPT / CPT / \\
SASW
\end{tabular} & 35.60048 & 140.10209 & $\begin{array}{c}\text { Chiba-g } \\
\text { /PARI }\end{array}$ & 0.128 & 0.16 & $\begin{array}{l}\text { No ground } \\
\text { failure }\end{array}$ \\
\hline $\begin{array}{l}\text { Inage, } \\
\text { Chiba }\end{array}$ & $\begin{array}{l}\text { CPT / } \\
\text { SASW } \\
\end{array}$ & 35.63469 & 140.07777 & $\begin{array}{l}\text { CHB024 } \\
\text { /K-NET }\end{array}$ & 0.237 & 0.07 & $\begin{array}{c}\text { Severe } \\
\text { liquefaction }\end{array}$ \\
\hline $\begin{array}{c}\text { Sunamachi, } \\
\text { Tokyo }\end{array}$ & $\begin{array}{l}\text { CPT / } \\
\text { SASW }\end{array}$ & 35.66226 & 139.83430 & $\begin{array}{l}\text { TKY013 } \\
\text { /K-NET }\end{array}$ & 0.144 & 0.06 & $\begin{array}{l}\text { No ground } \\
\text { failure }\end{array}$ \\
\hline $\begin{array}{c}\text { Tatsumi, } \\
\text { Tokyo }\end{array}$ & $\begin{array}{l}\text { CPT / } \\
\text { SASW }\end{array}$ & 35.64967 & 139.80849 & $\begin{array}{l}\text { TKY017 } \\
\text { /K-NET }\end{array}$ & 0.223 & 0.27 & $\begin{array}{l}\text { Moderate } \\
\text { liquefaction }\end{array}$ \\
\hline $\begin{array}{c}\text { Shinariake, } \\
\text { Tokyo }\end{array}$ & $\begin{array}{l}\mathrm{CPT} / \\
\text { SASW } \\
\end{array}$ & 35.62293 & 139.79100 & $\begin{array}{c}\text { Shinariake } \\
\text { /TMG }\end{array}$ & 0.122 & 0.12 & $\begin{array}{l}\text { No ground } \\
\text { failure }\end{array}$ \\
\hline $\begin{array}{c}\text { Tsuchiura, } \\
\text { Ibaraki }\end{array}$ & $\mathrm{SPT} / \mathrm{CPT}$ & 36.07283 & 140.19481 & $\begin{array}{l}\text { IBR014 } \\
\text { /K-NET }\end{array}$ & 0.506 & 0.01 & $\begin{array}{c}\text { Minor } \\
\text { liquefaction }\end{array}$ \\
\hline $\begin{array}{l}\text { Sendai, } \\
\text { Miyagi } \\
\end{array}$ & $\mathrm{SPT} / \mathrm{CPT}$ & 38.26597 & 140.92858 & $\begin{array}{l}\text { MYG013 } \\
\text { /K-NET }\end{array}$ & 1.547 & 0.01 & $\begin{array}{c}\text { Moderate } \\
\text { liquefaction }\end{array}$ \\
\hline $\begin{array}{c}\text { Ishinomaki, } \\
\text { Miyagi }\end{array}$ & $\mathrm{CPT}$ & & & $\begin{array}{l}\text { MYG010 } \\
\text { /K-NET }\end{array}$ & & 0.01 & $\begin{array}{c}\text { Moderate } \\
\text { liquefaction }\end{array}$ \\
\hline $\begin{array}{l}\text { Mihama- } \\
\text { ward, Chiba }\end{array}$ & $\begin{array}{l}\text { Adv. lab } \\
\text { tests / } \\
\text { SASW }\end{array}$ & 35.63096 & 140.05287 & $\begin{array}{l}\text { CHB024/ } \\
\text { K-NET }\end{array}$ & 0.237 & 2.283 & $\begin{array}{c}\text { No ground } \\
\text { failure to severe } \\
\text { liquefaction }\end{array}$ \\
\hline
\end{tabular}


Table 4. New Zealand sites for NGL database

\begin{tabular}{|c|c|c|c|c|}
\hline Project Name & $\begin{array}{c}\text { No. of } \\
\text { Sites }\end{array}$ & CPT & $\begin{array}{c}\text { Sonic } \\
\text { Boring }\end{array}$ & $\begin{array}{c}\text { Undisturbed } \\
\text { Sampling }\end{array}$ \\
\hline SM [34,35,41] & 8 & $\bullet$ & $\bullet$ & $\bullet$ \\
\hline CBD [36,37,38,42] & 8 & $\bullet$ & & $\bullet$ \\
\hline T\&T [39] & 12 & $\bullet$ & $\bullet$ & \\
\hline VT-UC [40] & 25 & $\bullet$ & & \\
\hline
\end{tabular}


Table 5. Example topics where supporting studies are needed for NGL liquefaction triggering model development

\begin{tabular}{|c|c|c|}
\hline Topic & Issues & Example references \\
\hline $\begin{array}{l}\text { Liquefaction } \\
\text { at depth }\end{array}$ & 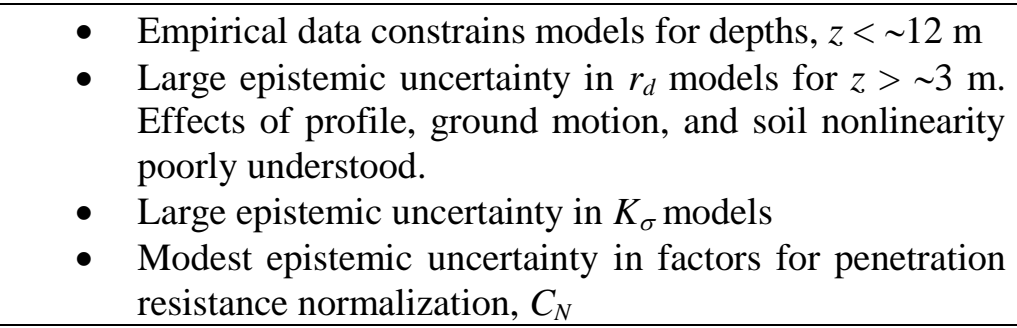 & $\begin{array}{l}r_{d}:[11,12,43,44] \\
K_{\sigma}:[12,45] \\
C_{N}:[11,13,45,46]\end{array}$ \\
\hline $\begin{array}{l}\text { Effects of } \\
\text { fines }\end{array}$ & $\begin{array}{l}\text { - Compared to clean sands, soils with fines have reduced } \\
\text { penetration resistance and different liquefaction } \\
\text { 'strength' or resistance for a given state (or relative } \\
\text { density, in case of non-plastic fines) } \\
\text { - Current modeling approaches are empirical, which } \\
\text { combines the two effects. Preferred approach is to } \\
\text { understand each effect and its sensitivity to fines content } \\
\text { and fines plasticity }\end{array}$ & $\begin{array}{l}\text { Effects on penetration } \\
\text { resistance: [47] } \\
\text { Effects on liquefaction } \\
\text { strength: [48] } \\
\text { Approximate combined } \\
\text { effects: all recent } \\
\text { triggering models }\end{array}$ \\
\hline $\begin{array}{l}\text { Ageing } \\
\text { effects }\end{array}$ & $\begin{array}{l}\text { - Empirical data is mostly from artificial fills and young } \\
\text { - Folocene) sediments } \\
\text { - For a constant relative density, older materials have } \\
\text { higher penetration resistance and higher liquefaction } \\
\text { resistance } \\
\text { - The increase of liquefaction resistance is greater than } \\
\text { predicted by the increased penetration resistance, so } \\
\text { additional corrections needed. }\end{array}$ & [49-52] \\
\hline $\begin{array}{lr}\text { Effects } & \text { of } \\
\text { static shear } \\
\text { stress }\end{array}$ & $\begin{array}{l}\text { - Effects of normalized static shear stress, } \alpha \text {, not included } \\
\text { in most current models. } \\
\text { - One published model for effect of } \alpha \text { on liquefaction } \\
\text { resistance, but lack of community consensus }\end{array}$ & [53] \\
\hline
\end{tabular}




\section{Figures:}

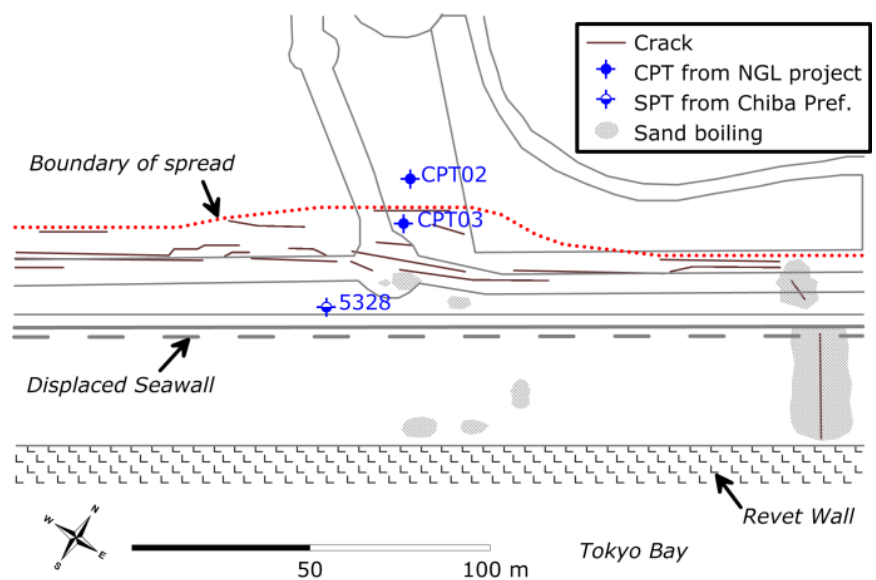

Figure 1. Sea front in Urayasu city where lateral spread occurred by the 2011 Tohoku Earthquake. 


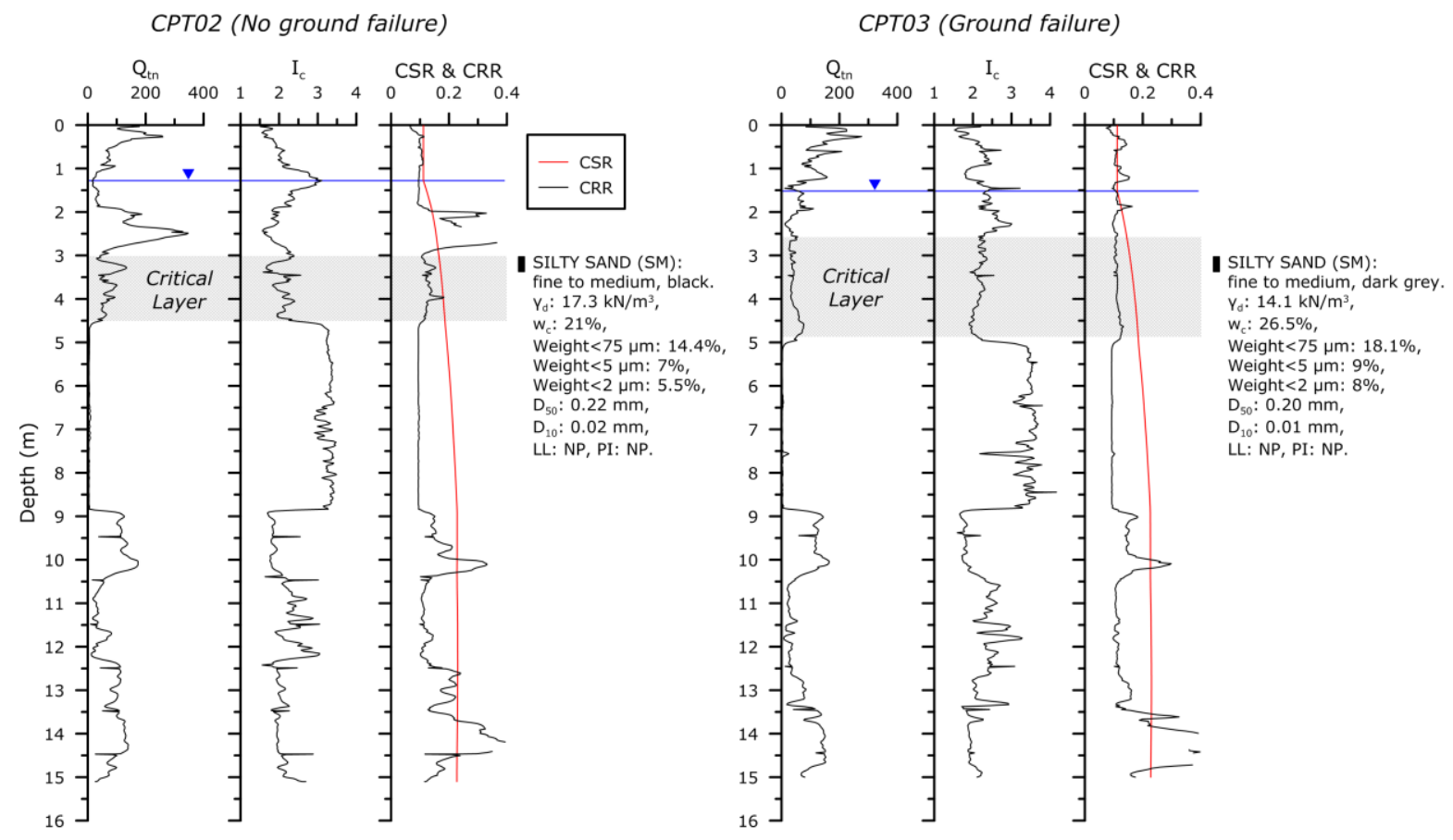

Figure 2. Normalized CPT resistance $\left(\mathrm{Q}_{\mathrm{tn}}\right)$, soil behavior type index $\left(\mathrm{I}_{\mathrm{c}}\right)$, cyclic stress ratio $(\mathrm{CSR})$ and cyclic resistance ratio (CRR) profiles on the location of no ground failure and ground failure. Laboratory index test results from the samples retrieved by a CPT sampler are indicated. 


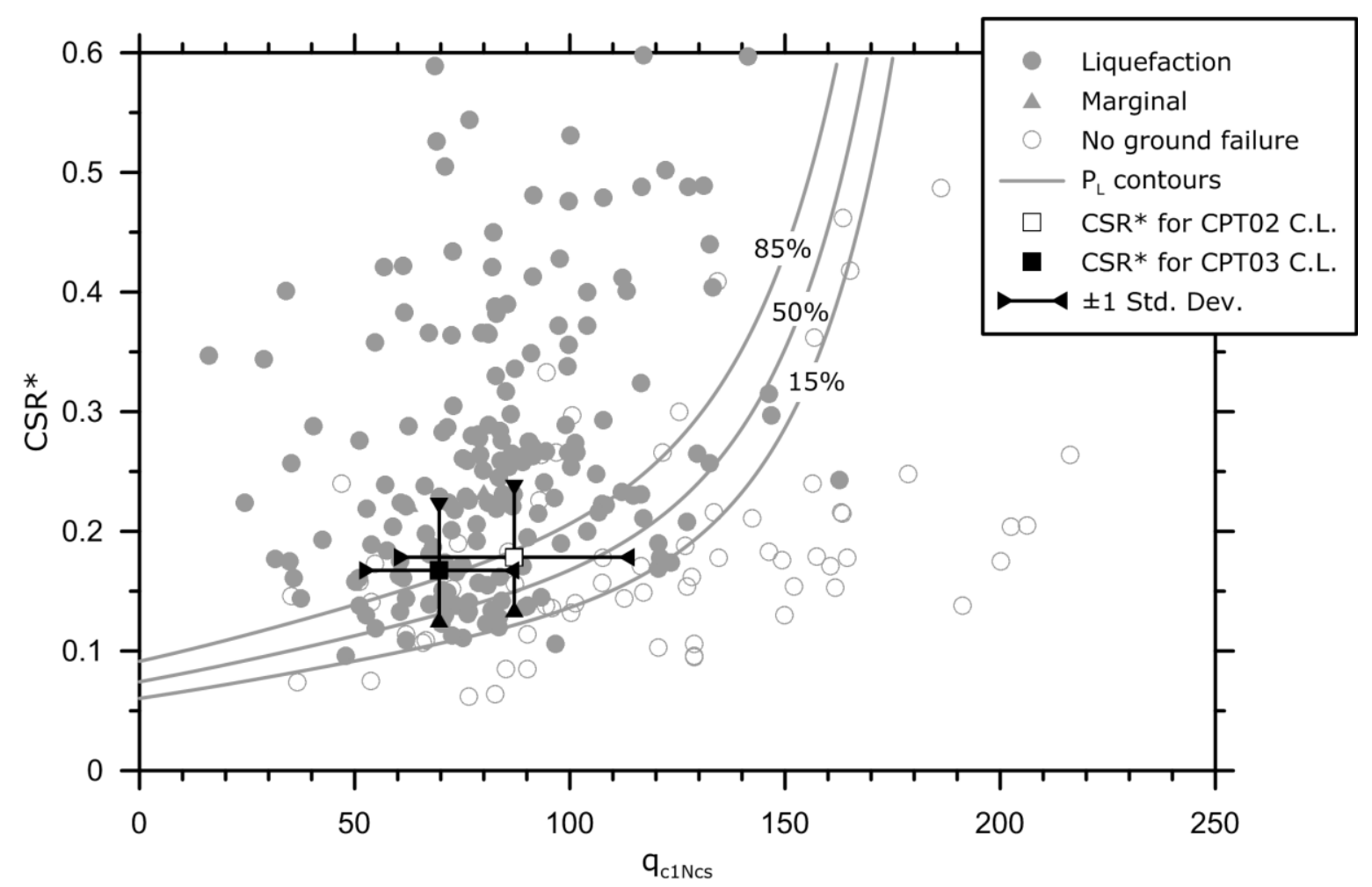

Figure 3. Liquefaction triggering database showing $C S R^{*}$ vs. $q_{c I N c s}$ and $C R R_{M 7.5, \sigma^{\prime}=1 a t m}$ for 15,50 , and $85 \%$ probabilities of liquefaction [7]. Data points for critical layers and \pm 1 standard deviations of $C S R^{*}$ and $q_{c I N c s}$ are shown for no ground failure (CPT02) and ground failure (CPT03) locations at example site in Urayasu, Japan. 


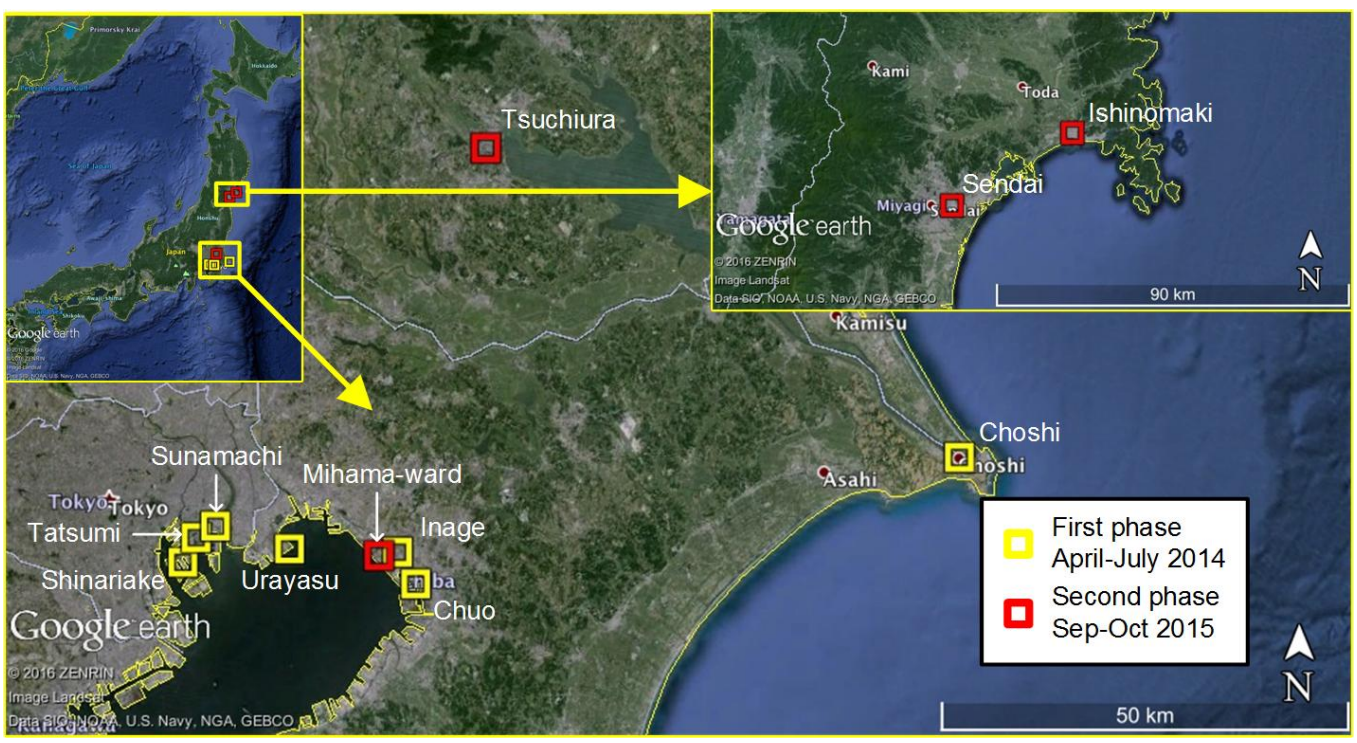

Figure 4. Locations of ground failure or non-ground failure sites investigated in first phase of NGL characterization work in Japan (base map from Google Earth ${ }^{\mathrm{TM}}$ ). 


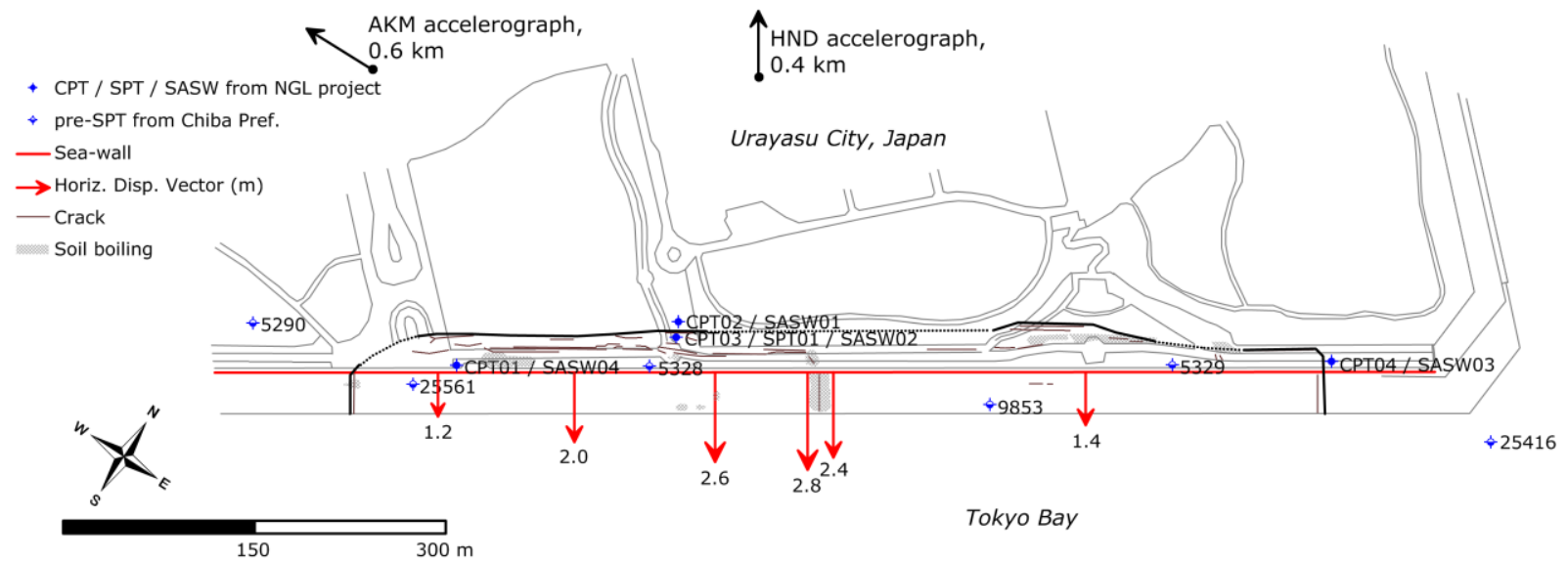

Figure 5. Plan view of Urayasu sea front where lateral spread occurred during 2011 M 9.0 Tohoku earthquake mainshock. All surface features based on field mapping, ground and air photos, and LiDAR imaging. 


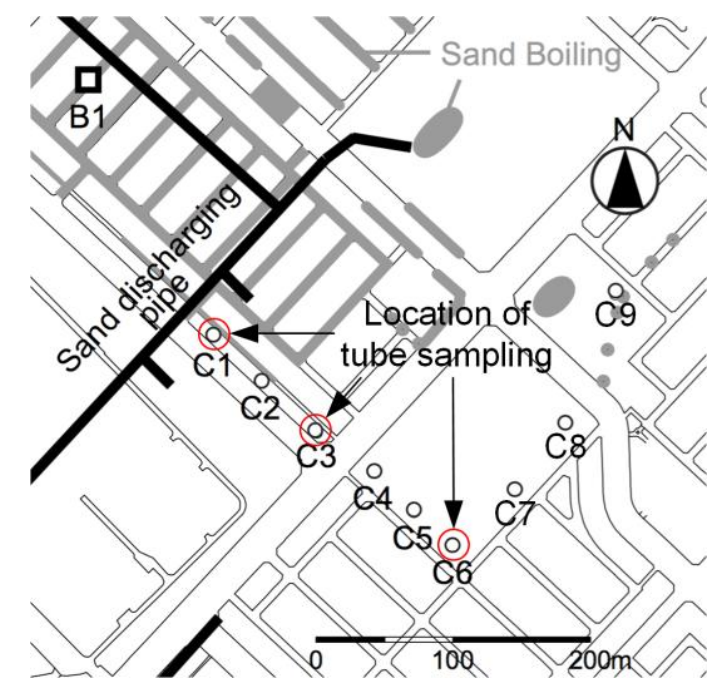

Figure 6. Mihama-ward site showing CPT locations, sand discharging pipe, and sand boiling traces [31]. 


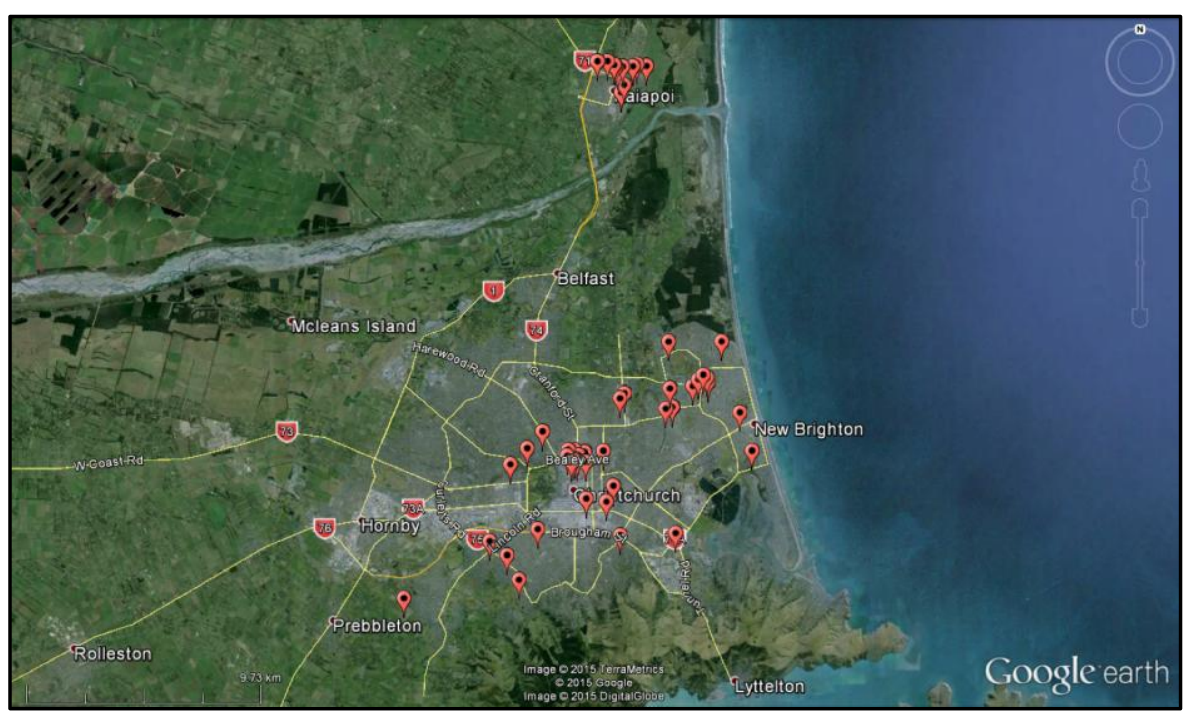

Figure 7. Geographic distribution of NGL New Zealand sites in the Canterbury Region 